\title{
References
}

1. Manková, M., Lišuchová, O. 2019. Manažment nutrície a hygieny. str. 216-221. In: Vansáč P, Czarnecki P, Popovičová M: Zborník vedeckých prác V. Medzinárodnej vedeckej konferencie: Nevyhnutnost' dlhodobej sociálno-zdravotnej starostlivosti v Slovenskej republike. Collegium Humanum - Szkola Glowna Menedzerska, Warszawa 2019,254 s. ISBN 978-83-952951-0-2.

2. Kissová, V. 2016. Základy klinickej výživy. Učebný text pre študentov medicíny. Vydavatel’stvo UKBA, Bratislava, 1.vyd. 2016, 68 str.

3. Belovičová, M. 2019. Malnutrícia vo vybraných skupinách chronicky chorých pacientov. str. 114-121. In: Vansáč P, Czarnecki P, Popovičová M: Zborník vedeckých prác V. Medzinárodnej vedeckej konferencie: Nevyhnutnost' dlhodobej sociálno-zdravotnej starostlivosti v Slovenskej republike. Collegium Humanum - Szkola Glowna Menedzerska, Warszawa 2019, 254 s. ISBN 978-83-952951-0-2.

4. Krajčík, Š., Mikuš, P., Bajanová, E. a kol. 2018. Výživa vo vyššom veku. Herba. Bratislava, 1.vyd. 2018,189 str. ISBN 978-80-89171-841.

5. Groce, N., Challenger, R., Berman-Bieler, A. et al 2014. Malnutrition and disability: unexplored opportunities for collaboration. In: Paediatrics International Child Health; 2014; 34(4): 308-314.

6. Role of the Dietitian in the Disability Setting. 6/2010. Irish Nutrition and Dietetic Institute (INDI). Fact Sheet.

7. Position of the Academy of Nutrition and Dietetics: Nutrition Services for Individuals with Intellectual and Developmental Disabilities and Special Health Care Needs. In Journal of the Academy od Nutrition and Dietetics. 2015; 115(4): 593-608.

DOI 10.24144/2077-6594.3.2.2020.213731

Ivanková V., Belovičová M.

\section{Consequences of chronic wounds on patient's life}

\author{
St. Elizabeth University of Health and Social Sciences, Field office in Michalovce, Slovakia
}

vierkai@centrum.sk,mriab9@gmail.com

Chronic wounds are a health problem that has a negative impact on patients' lives and contributes to the increased costs of the healthcare system. They are often perceived as a disease of the elderly, because its peak incidence is between the ages of 60 and 80 , but it is clear that the onset of one's disease can date back to productive age.

If we consider the consequences of chronic wounds on patients' lives, we cannot forget to mention social discomfort, mobility problems, unpleasant odour, etc. Chronic wounds can cause significant physical disability, chronic pain, which can lead to permanent disability of the patient, to the need for assisted housing, depression, social isolation, or even to death.

Negative aspects of chronic wounds are reviewed in terms of quality of life and in terms of economic costs. Reliable socio-economic data in this area are limited. Chronic wounds present high costs for health care services because they require home care, long-term hospitalizations, comprehensive treatments and adjuvant treatments, and are associated with a high recurrence rate. In this context, people with chronic wounds experience changes in body image, mobility disorders, lack of self-care, inability to perform daily activities, pain and discomfort, which negativelly effects the quality of one's life [1].

In patients with chronic wounds, we observe a disruption of their partnerships and family relationships, which also has a negative impact on the intimate and sexual life of patients with chronic wounds [2]. The European Wound Management Association (EWMA) found a significant link between a patient's mental well-being and basic physiological processes in wound healing [3].

To evaluate the effects of the disease and its treatment on human life validated tools and scales are used. They serve as an indicator of the response to treatment in people with chronic wounds, taking into account physical, psychological and social aspects, functional status and vision of life [4].

As part of a nursing practice, the nurses are in close contact with chronic wound patients. In this regard, it is important that they have sufficient skills and knowledge in the field of chronic wound healing [5], that they are erudite not only medically but also socially, so they can provide the patients and their families with true and appropriate advice in this area.

In the case of chronic wounds, depending on the indication, supportive communication, psychotherapy and psychopharmacological treatment should be considered. Effective communication with the patient can reveal several problems in the area of the their psychosomatic problems, and it is always good if the patient can find in their nurse a psychological help and a support for solving their problems. Neither must we forget to satisfy the inner - spiritual needs of the patient. 
Modern medicine and nursing call for the need for comprehensive treatment and patient care and for an individual approach to the treatment of chronic wounds. It is necessary to perceive the patient as a holistic being and to comprehensively evaluate all factors influencing the wound healing process [5].
Key words: chronic wound, consequences of chronic wounds on patients' lives, quality of life, comprehensive treatment of chronic wounds.

\title{
References
}

1. Newbern, S. Identification of pain and effects on quality of life from chronic wounds to secondary vascular disease with lower extremity: An integrated review. Adv Skin Care Wound Care. 2018; 31 (3): 102-8.

2. Posnett, J., Franks, P., J.2008. The burden of chronic wounds in the UK. Nursing Times, 2008, 104:3, 44-45. [online]. [cit. 2020-08-01]. Available online: https://www.nursingtimes.net/clinical-archive/tissue-viability/the-burden-of-chronicwounds-in-the-uk-23-01-2008.

3. Palfreyman, S. Assessing the impact of venous ulceration on quality of life. Nursing Times, 2008, 104(41): 34-37.

4. Cavassan, N.,R.,V. et al. 2018. Correlation between chronic venous ulcer exudate proteins and clinical profile: A cross-sectional study. J Proteomics. 2018; 192: 280-90.

5. Popovičová, M. Novyje napravlenija po zaživleniju ran. Ukrajina. Zdorovja naciji, 2020, 3(60): 120-124. ISSN 2077-6594.

Балашов К.В.

\section{Ефективна комунікація між лікарем та паціснтом: міжнародний досвід і науково-методологічна основа}

\author{
Національна медична академія післядипломної освіти імені П.Л. Шупика, м. Київ, Україна
}

За даними MO3 України станом на початок 2019 року у нашій країні налічувалося 2,6 млн осіб з інвалідністю, 3 них 161 тис. дітей. Більшість із них потребують реабілітації. Вчасне та адекватне надання реабілітаційної допомоги таким пацієнтам дозволяє запобігти виникненню додаткових обмежень, сприяє максимально можливому відновленню функцій організму та пристосуванню до активного життя.

Відповідно до Наказу МО3 України від 13.12.2018 № 2331 "Про внесення змін до Довідника кваліфікаційних характеристик професій працівників. Випуск 78 «Охорона здоров'я»" лікар фізичної та реабілітаційної медицини має вміти організувати командну взаємодію між фахівцями, залученими до реабілітації, знати форми і методи санітарної освіти, інформаційні та інтернет-технології (Офіційний веб-сайт МОЗ України, 2020).

Таким чином, існує потреба у навчанні лікарів фізичної та реабілітаційної медицини основ здійснення міжособистісної та публічної комунікації на до- та післядипломному рівні з метою формування адекватного розуміння цілей, засобів і можливостей реабілітаційних заходів на популяційному рівні й формування прихильності до лікування у конкретного пацієнта.

Мета: надати рекомендації щодо підготовки лікарів фізичної та реабілітаційної медицини з питань здійснення міжособистісної комунікації в межах безперервного професійного розвитку лікарів.
Матеріали та методи. За допомогою бібліосемантичного методу та використання контентаналізу опрацьована актуальна наукова та довідникова література щодо розробки та здійснення комунікації у сфері охорони здоров'я, зокрема нормативні документи ВОО3, програми підготовки лікарів в Україні та закордоном, наукові публікації щодо здійснення комунікацій в охороні здоров'я.

Результати. Фундамент модернізації системи комунікацій в охороні здоров'я був визначений Люблянською Хартією (1996р.), яка сформулювала вимоги до систем охорони здоров'я в Свропі (Москаленко, Гульчій, \& Грузєва, 2013), які мають бути:

- засновані на етичних цінностях, що передбачає підтримку гідності людини, справедливість, солідарність, професійну етику;

- спрямовані на поліпшення здоров'я;

- спрямовані на задоволення потреб населення, поряд із взяттям на себе громадянами частки відповідальності за своє здоров'я;

- орієнтовані на первинну медико-санітарну допомогу.

Сучасне розуміння мети i завдань комунікації викладене у (Слабкий, Миронюк, \& Качала, 2017) та (Знаменська, 2015) i розглядає комунікацію, як рівноправний обмін інформацією, що вимагає «вміння 